\title{
Meiotic behavior in wild and domesticated species of Passiflora
}

\author{
MARGARETE MAGALHÃES SOUZA ${ }^{1,3}$ and \\ TELMA NAIR SANTANA PEREIRA ${ }^{2}$
}

(received: April 29, 2010; accepted: January 20, 2011)

\begin{abstract}
Meiotic behavior in wild and domesticated species of Passiflora). The meiotic behavior of fourteen Passiflora taxa was analyzed. The species were grouped according to the $n$ value $(6,9$ and 12) for statistical studies. Some species presented tetravalent associations or univalent chromosomes in diakinesis, bivalent formation prevailing. The qui-square test revealed significant differences in the chiasma frequency among species for $n=9$ and $n=6$ groups. There was predominance of interstitial chiasmata in almost all studied species. The $n=12$ group was the only one whose meiotic behavior was considered similar due to the quantity of chiasmata per cell, tendency of interstitial chiasma localization. Some species presented meiotic irregularities, such as laggard and precocious chromosomes in meiosis I. In telophase II the percentages of meiotic irregularities was low. Irregularities in the spindle orientation were presented in higher percentages in the end of meiosis II, and were also responsible for post-meiotic abnormal products. The irregularities observed during meiosis can have influence on the percentage of sterile pollen grains and success of interspecific crossings in Passiflora species.
\end{abstract}

Key words - chiasmata, meiotic index, microsporogenesis, passion flower, post-meiotic products

RESUMO - (Comportamento meiótico em espécies silvestres e domesticadas de Passiflora). O comportamento meiótico de 14 táxons foi analisado. As espécies foram agrupadas de acordo com o valor de $n$ (6, 9 e 12) para estudos estatísticos. Algumas espécies apresentaram associações tetravalentes ou cromossomos univalentes em diacinese, prevalecendo formação de bivalentes. O teste de qui-quadrado revelou diferenças significativas na freqüência de quiasmas entre espécies para grupos $\operatorname{com} n=9$ e $n=6$. Houve predominância de quiasmas intersticiais em quase todas as espécies estudadas. O grupo com $n=12$ foi o único cujo comportamento meiótico foi considerado similar devido à quantidade de quiasmas por célula, tendência à localização intersticial de quiasmas. Algumas espécies apresentaram irregularidades meióticas, tais como cromossomos retardatários ou precoces em meiose I. Na telófase II os percentuais de irregularidades meióticas foram baixos. Irregularidades na orientação das fibras dos fusos ocorreram em alto percentual no final da meiose II, sendo também responsáveis por produtos pós-meióticos anormais. As irregularidades observadas durante a meiose podem ter influência sobre o percentual de grãos de pólen estéreis e o sucesso de cruzamentos interespecíficos em espécies de Passiflora.

Palavras-chave - índice meiótico, microsporogênese, produtos pós-meióticos, quiasmas

\section{Introduction}

The genus Passiflora L. (Passifloraceae) is made up of more than 500 species (Cervi 2005) which are widespread in the tropics. Many of such species can be found in tropical America, mainly in Brazil (Oliveira 1987). The Brazilian North-central region is considered the center of geographic distribution of the genus Passiflora, which presents the highest number of species, out of which ninety per cent originate in America (Lopes 1991). The genus Passiflora has high inter and intra-specific genetic variability (Viana et al.2003). Among the species, P. edulis Sims (purple passion fruit) is the cultivated species, and P. edulis f. flavicarpa O. Deg. (yellow passion fruit) has high agronomic value.

1. Universidade Estadual de Santa Cruz (UESC), Departamento de Ciências Biológicas, Pavilhão Jorge Amado, Rod. Ilhéus-Itabuna, km 16, 45662-900 Ilhéus, BA, Brazil.

2. Universidade Estadual do Norte Fluminense Darcy Ribeiro (UENF), Centro de Ciências e Tecnologias Agropecuárias, Campos dos Goytacazes, RJ, Brazil.

3. Corresponding author: souzamagg@yahoo.com.br
Both are cultivated for production of industrialized juice and in natura consumption. Other species have edible fruits, such as $P$. alata Dryand (sweet passion fruit), $P$. ligularis Juss. (urucu passion fruit), P. mollissima Bailey (curuba passion fruit) and P. quadrangularis L. (melon passion fruit) (Martin \& Nakasone 1970), but they are almost unexplored.

Albeit they can be considered in a privileged condition as far as their genetic characteristics are concerned, an unfortunate genetic deterioration has struck the passion flower (Abreu et al. 2009). The processes of urbanization or expansion of agricultural activities have had the result of reducing the genetic diversity and the population size (Ferreira 2005). Hence the conservation of the germplasm of wild species is necessary to maintain the genetic variability and permit future access to these collections (Abreu et al. 2009).

Chromosomes remain important not simply because they carry the genes, but because their behaviour determines the mechanism of inheritance (Sumner 2003). The fertility of an individual depends, in large part, on 
meiotic regularity, and some genes which affect meiosis have already been described (Gottschalk \& Kaul 1980, Bione et al. 2002, Li et al. 2003). If the events that occurred during meiosis are under genetic control, they are mutable (Defani-Scoarize et al. 1996), causing some irregularities such as laggard chromosomes (Consolaro \& Pagliarini 1996) and spindle orientation abnormalities (Tilquin et al. 1984, Caetano-Pereira et al. 1998). Such irregularities are not desirable since they affect the genotypes producing unviable gametes, which many times make the interspecific hybridization difficult for genetic breeding programs.

Passiflora species have been used to decorate European greenhouses and gardens since their introduction in the Old World, around the seventeenth century (Peixoto 2005). In the United States, the passion flowers are cultivated in gardens, on walls, fences, pergolas, greenhouses and conservatories (Vanderplank 2000, Rushing 2003). However, artificial interspecific hybrids have more ornamental importance and nowadays there are more than 500 of them registered (Abreu et al. 2009). In this study, the meiotic behavior in Passiflora taxa was analyzed for use in breeding programs.

\section{Material and methods}

The samples studied consisted of fourteen taxa, part originating from seeds and cuttings collected in the North of the state of Rio de Janeiro and in the Região dos Lagos (RJ), Brazil, and part donated by several Brazilian institutions. The plants were cultivated in a greenhouse, in the Research Support Unit of UENF. Voucher specimens of the material collected were deposited in the herbarium of the Instituto Agronômico de Campinas (IAC), SP, Brazil. The specimens analyzed, provenance, voucher numbers and number of chromosomes are listed in table 1.

The flower buds were fixed in ethanol-acetic acid 3:1, for 2 to 3 hours at room temperature, with transference to fresh fixative three times during this period, and kept at $-20{ }^{\circ} \mathrm{C}$. Temporary slides were prepared by the squashing technique and the cells were stained with $1 \%$ acetic carmine. At least 50 cells of each meiotic phase were analyzed. Rod bivalents were scored as containing one chiasma and ring bivalents as having two chiasmata (Senda et al. 2005). The frequency of terminal, interstitial and total chiasmata in species with the same gametic chromosome number $(n=6$, $n=9$ and $n=12$ ) were compared through the qui-square test to verify differences among species, using the contingency tables $3 \times 2.9 \times 2$ and $2 \times 2$, respectively. The recombination index $\left(R I=\left[\sum\right.\right.$ total number of chiasmata $\div$ number of cells analyzed] $+n$ value) was calculated according to Darlington (1958). The quantities of the post-meiotic products (monads, dyads, triads, tetrads and polyads) were registered for the calculation of meiotic index $(\% \mathrm{MIx}=[$ number of normal tetrads $\times 100] \div$ number of counted post-meiotic products (PMP) (Love 1951), and ANOVA, considering a randomized experimental design. For the calculation of MIx mean, the counting of post-meiotic products was used in four slides (repetitions), being sampled, at random, two anthers

Table 1. Provenance, voucher number and chromosome number (first authors) of Passiflora.

\begin{tabular}{|c|c|c|c|}
\hline Taxa & Provenance and voucher number & $n$ & $2 n$ \\
\hline P. alata Dryand. & IAC-41.613 & 9 (Beal 1969) & 18 (Guerra 1986) \\
\hline P. amethystina Mikan & Rio de Janeiro & 9 (present study) & 18 (Barbosa \& Vieira 1997) \\
\hline P. capsularis $\mathrm{L}$. & IAC, Campinas & 6 (present study) & 12 (Bowden 1945) \\
\hline P. cincinnata Mast. & IAC-41.799 & 9 (Melo et al. 2001) & $18($ Beal 1971) \\
\hline P. edulis Sims & UNESP, Jaboticabal & 9 (Storey 1950$)$ & 18 (Janaki Ammal 1945) \\
\hline $\begin{array}{l}\text { P. edulis f. Alavicarpa } \\
\text { O. Deg. }\end{array}$ & $\begin{array}{l}\text { Comercial crop Field, in São } \\
\text { Francisco de Itabapuana, RJ }\end{array}$ & 9 (Storey 1950) & 18 (Storey 1950) \\
\hline $\begin{array}{l}\text { P. gibertii N.E. } \\
\text { Brown }\end{array}$ & $\begin{array}{l}\text { UNESP, Jaboticabal. } \\
\text { IAC- } 41.800\end{array}$ & $\begin{array}{l}9 \text { (Oliveira \& } \\
\text { Coleman 1996) }\end{array}$ & 18 (Oliveira \& Coleman 1996) \\
\hline $\begin{array}{l}\text { P. kermesina Link \& } \\
\text { Otto }\end{array}$ & $\begin{array}{l}\text { Marataízes, ES; Conceição de } \\
\text { Macabú, RJ. Flowers, } \\
\text { IAC-41.798; fruit, IAC-41.801 }\end{array}$ & 9 (present study) & 18 (Guerra 1986) \\
\hline P. malacophylla Mast. & IAC-41.791 & 9 (present study) & 18 (Souza et al. 2003b) \\
\hline P. morifolia Mast. & IAC, Campinas & 6 (MacDougal 1983) & 12 (Melo et al. 2001) \\
\hline P. mucronata Lam. & $\begin{array}{l}\text { Grussaí, Campos dos Goytacazes, } \\
\text { RJ. IAC-41.796 }\end{array}$ & 9 (present study) & 18 (Guerra 1986) \\
\hline P. pentagona Mast. & IAC-41.611 & 12 (Melo et al. 2001) & 24 (Melo et al. 2001) \\
\hline P. rubra L. & Rio de Janeiro & 6 (present study) & 12 (Snow \& MacDougal 1993) \\
\hline P. suberosa L. & Natividade, RJ. IAC-41.797 & 12 (Storey 1950) & 24 (Storey 1950) \\
\hline
\end{tabular}


of different flowers per trial, adding up to four analyzed plants. For comparison among averages the Tukey test was used. The data were analyzed using the GENES program (Cruz 2006).

\section{Results}

Chromosomal pairing and chiasmata frequency were observed in meiocytes in diakinesis. The species presented different chromosomal associations (table 2; figures 1-15), showing bivalent associations in most cells investigated, but tetravalent associations or univalent chromosomes at diakinesis were observed. As a consequence, the chromosomal segregation was abnormal in further meiotic phases. The mean number and position of chiasmata per cell, and RI were observed (table 3) and the application of qui-square test (table 4) revealed that: a) there was difference in the chiasmata frequency among Passiflora taxa for groups with $n=6$ and $n=9$; b) there was difference in the chiasmata localization for all tested groups, with predominance of interstitial chiasmata in all studied species, except P. kermesina.

Some irregularities were observed during meiosis I and II (figures 1-28), the species presenting different percentages of irregularity in the different phases analyzed (table 5). Many precocious chromosomes observed in metaphase I remained in anaphase I and during the second meiotic division (figures 9-13).
Some cells presented irregularity in the orientation of spindles in meiosis II, which made both groups of the same cell present the chromosomal alignment in the equatorial plate in a differentiated way, mainly in " $T$ " format, thus characterizing the formation of transverse spindles (figures 15-16), or "V", characterizing tripolar spindles (figures 17-20). As a consequence, some cells in telophase II did not present a symmetric position of the nucleus except one, non-aligned (figure 18 ), what is compatible with the irregular organization observed in anaphase II. Some cells presented just three groups of chromosomes instead of four in telophase II (figure 24).

The species less affected by spindles irregularities were P. alata, P. edulis f. flavicarpa and P. malacophylla, while the most affected ones were $P$. suberosa, $P$. pentagona and $P$. morifolia, with more than $15 \%$ of cells affected in the three phases analyzed of meiosis II. In meiosis II, there was also asynchrony during cell division within the same cell. Some cells presented a group of chromosomes in metaphase while the other group was disorganized (figures 21-22). Other cells presented only one group which had completed the anaphase (figure 23).

Irregular post-meiotic groups were observed, such as monads, dyads, triads and polyads (table 6; figures 1628). Triad was the irregularity found in all species, varying from $1.6 \%$ in $P$. amethystina to $9.9 \%$ in $P$. suberosa. The MIx was higher than $90 \%$ in all species, except for

Table 2. Chromosome pairing configurations (\%) at diakinesis in Passiflora $(\mathrm{I}=$ univalents; II = bivalents; IV = tetravalents).

\begin{tabular}{|c|c|c|c|c|c|c|c|c|}
\hline Taxa & & & Chro & mosome pairing & g configurations & $(\%)$ & & \\
\hline $2 n=12$ & $6 \mathrm{II}$ & $5 \mathrm{II}+2 \mathrm{I}$ & $4 \mathrm{II}+1 \mathrm{IV}$ & $2 \mathrm{II}+2 \mathrm{IV}$ & $3 \mathrm{IV}$ & & & \\
\hline P. capsularis & 87.6 & 11.2 & 0.6 & - & 0.6 & & & \\
\hline P. morifolia & 90.0 & - & 6.7 & 3.3 & - & & & \\
\hline P. rubra & 91.4 & 6.2 & 1.6 & 0.8 & - & & & \\
\hline $2 n=18$ & 9II & $8 \mathrm{II}+2 \mathrm{I}$ & $7 \mathrm{II}+1 \mathrm{IV}$ & $7 \mathrm{II}+4 \mathrm{I}$ & $6 \mathrm{II}+1 \mathrm{IV}+2 \mathrm{I}$ & $5 \mathrm{II}+2 \mathrm{IV}$ & $5 \mathrm{II}+1 \mathrm{IV}+4 \mathrm{I}$ & $18 \mathrm{I}$ \\
\hline P. alata & 74.2 & 7.4 & 4.8 & 8.0 & 2.0 & 1.8 & 1.8 & - \\
\hline P. amethystina & 93.0 & 6.3 & 0.7 & - & - & - & - & - \\
\hline P. cincinnata & 93.8 & - & 6.2 & - & - & - & - & - \\
\hline P. edulis & 100.0 & - & - & - & - & - & - & - \\
\hline P. edulis f. flavicarpa & 97.1 & 2.9 & - & - & - & - & - & - \\
\hline P. gibertii & 86.7 & 8.6 & - & 1.2 & 3.5 & - & - & - \\
\hline P. kermesina & 86.0 & - & 11.0 & - & - & 2.0 & - & 1.0 \\
\hline P. malacophylla & 91.8 & - & 8.2 & - & - & - & - & - \\
\hline P. mucronata & 85.0 & 8.9 & 2.0 & - & 4.1 & - & - & - \\
\hline $2 n=24$ & $12 \mathrm{II}$ & $11 \mathrm{II}+2 \mathrm{I}$ & $10 \mathrm{II}+4 \mathrm{I}$ & $9 \mathrm{II}+2 \mathrm{I}+1 \mathrm{IV}$ & $9 \mathrm{II}+6 \mathrm{I}$ & $8 \mathrm{II}+2 \mathrm{IV}$ & $8 \mathrm{II}+41+1 \mathrm{IV}$ & \\
\hline P. pentagona & 86.2 & 9.2 & 1.0 & - & - & 3.6 & - & \\
\hline P. suberosa & 85.0 & 5.1 & 2.1 & 4.9 & 2.4 & - & 0.5 & \\
\hline
\end{tabular}




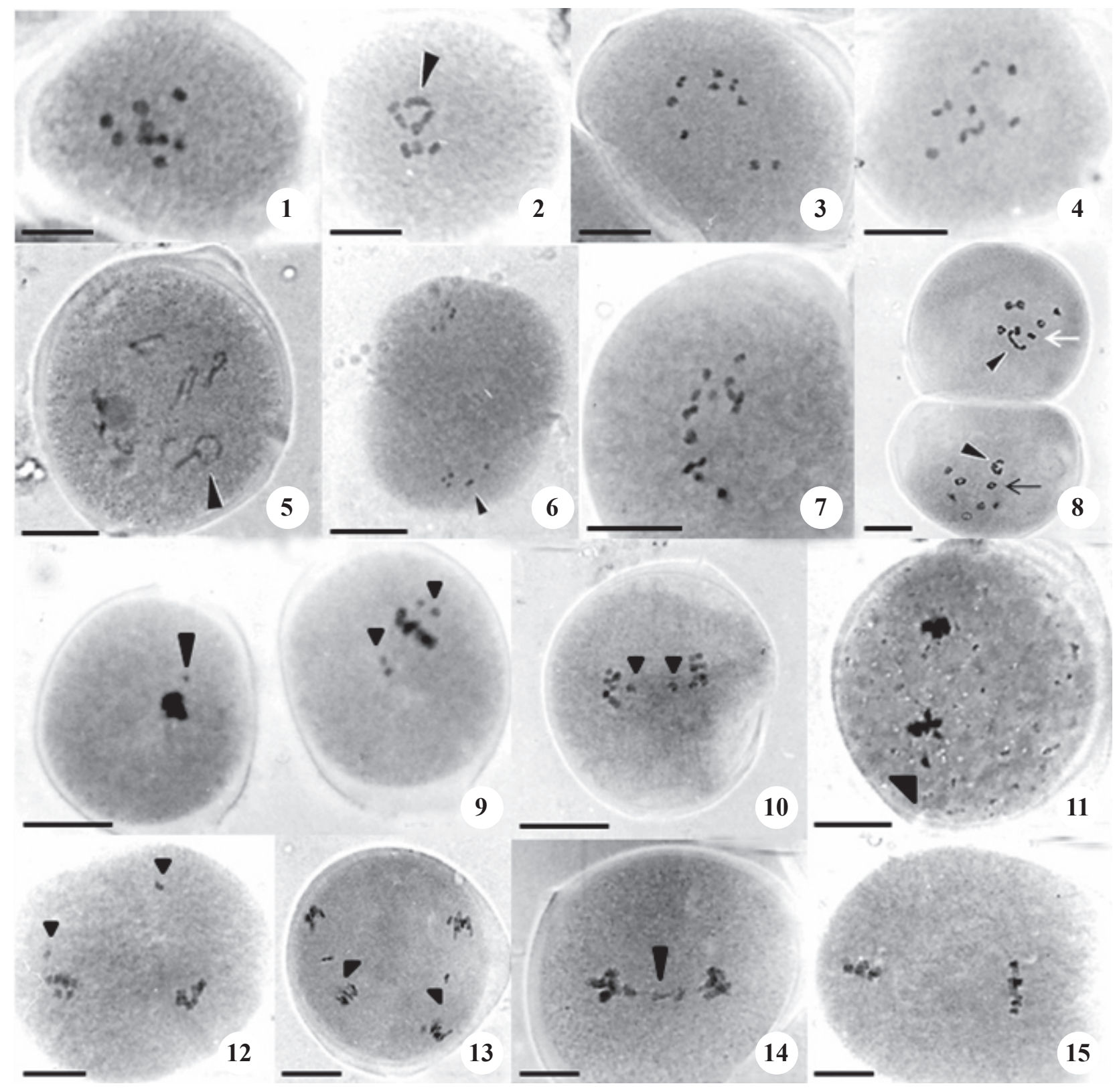

Figures 1-15. Meiotic behavior in Passiflora. 1-2. Configurations of chromosome pairing. 1. Passiflora amethystina with 9 bivalents in diakinesis. 2. Passiflora morifolia with 7 II +1 IV (arrowhead) in diakinesis. 3. Passiflora mucronata with 9 bivalents in prometaphase. 4. Passiflora malacophylla with 9 bivalent in prometaphase. 5. Passiflora alata with 7 II +1 IV (arrowhead) in diploteno. 6. Passiflora rubra with 4 II + 1 IV (arrowhead) in prometaphase. 7. Passiflora suberosa with 12 bivalents in diakinesis. 8. Passiflora kermesina with 7 II + 1 IV (arrowheads) in diakinesis; terminal (black arrow) and insterstitial (white arrow) chiasmata. 9. Metaphase I with precocious chromosomes (arrowheads) in P. suberosa. 10. Anaphase I with precocious chromosomes (arrowheads) in P. suberosa. 11. Telophase I with precocious chromosomes (arrowhead) in $P$. kermesina. 12. Metaphase II with precocious chromosomes (arrowheads) in $P$. gibertii. 13. Anaphase II with precocious chromosomes (arrowheads) in P. kermesina. 14. Telophase I with chromosome bridge without fragments (arrowhead) in $P$. alata. 15. Metaphase II in $P$. kermesina with transverse spindles. Bar $=20 \mu \mathrm{m}$.

P. pentagona $(88.8 \%)$ and $P$. suberosa $(88.4 \%)$. The mean squares evidenced significant differences through the $\mathrm{F}$ test for irregularities in the post-meiotic products (table 7). The means obtained for MIx were compared through the Tukey test and provided the recognition of four taxa groups, with MIx of: a) from 97.7 to 98.1, b) from 95.2 to 96.2, c) from 92.4 to 93.1, d) from 88.4 to 88.8 (table 6). 
Table 3. Chiasmata number observed at diakinesis per cell and recombination index (RI) in Passiflora (Min $=$ minimum; $\mathrm{Max}=$ maximum; se $=$ standard error; $\mathrm{TCh}=$ Total chiasmata).

\begin{tabular}{|c|c|c|c|c|c|c|}
\hline \multirow{2}{*}{ Taxa and chromosome numbers } & \multirow{2}{*}{$\begin{array}{c}\text { Terminal } \\
\text { Mean }\end{array}$} & \multicolumn{3}{|c|}{ Interstitial } & \multirow{2}{*}{$\begin{array}{l}\text { TCh } \\
\text { Mean }\end{array}$} & \multirow{2}{*}{ RI } \\
\hline & & $($ Min-max \pm se $)$ & Mean & $($ Min-max $\pm \mathrm{se})$ & & \\
\hline \multicolumn{7}{|l|}{$n=6$} \\
\hline P. capsularis & 0.40 & $(2-2 \pm 0)$ & 5.30 & $(3-6 \pm 1.15)$ & 5.70 & 11.9 \\
\hline P. morifolia & 3.26 & $(0-8 \pm 2.32)$ & 4.36 & $(2-7 \pm 1.24)$ & 7.60 & 13.7 \\
\hline P. rubra & 1.80 & $(0-4 \pm 0.97)$ & 4.80 & $(4-6 \pm 0.91)$ & 6.60 & 12.5 \\
\hline \multicolumn{7}{|l|}{$n=9$} \\
\hline P. alata & 4.20 & $(0-6 \pm 0.16)$ & 4.50 & $(1-10 \pm 0.58)$ & 8.70 & 17.6 \\
\hline P. amethystina & 3.06 & $(0-8 \pm 1.08)$ & 6.80 & $(3-9 \pm 0.92)$ & 9.93 & 18.9 \\
\hline P. cincinnata & 5.41 & $(0-12 \pm 0.90)$ & 6.16 & $(3-9 \pm 1.02)$ & 11.58 & 20.6 \\
\hline P. edulis & 4.10 & $(0-12 \pm 0.91)$ & 6.95 & $(4-9 \pm 0.79)$ & 11.05 & 20.2 \\
\hline P. edulis f. flavicarpa & 4.00 & $(1-12 \pm 0.73)$ & 6.85 & $(4-9 \pm 0.84)$ & 10.85 & 19.9 \\
\hline P. gibertii & 3.56 & $(0-8 \pm 0.78)$ & 5.40 & $(2-9 \pm 0.88)$ & 8.96 & 17.8 \\
\hline P. kermesina & 4.90 & $(1-8 \pm 0.58)$ & 4.40 & $(1-8 \pm 0.75)$ & 9.30 & 18.5 \\
\hline P. malacophylla & 4.27 & $(1-12 \pm 0.62)$ & 10.45 & $(3-14 \pm 0.98)$ & 14.72 & 23.9 \\
\hline P. mucronata & 2.65 & $(0-7 \pm 0.65)$ & 6.75 & $(3-11 \pm 0.22)$ & 9.45 & 18.5 \\
\hline \multicolumn{7}{|l|}{$n=12$} \\
\hline P. pentagona & 3.34 & $(0-6 \pm 0.16)$ & 8.61 & $(6-12 \pm 0.52)$ & 12.03 & 24.1 \\
\hline P. suberosa & 1.83 & $(0-6 \pm 0.39)$ & 10.29 & $(8-12 \pm 0.45)$ & 12.20 & 24.2 \\
\hline
\end{tabular}

Table 4. Chi-square test $\left(\chi^{2}\right)$ for frequency $(f)$ of total, terminal (T) and interstitial (I) chiasmata, grouped according to gametic chromosome number $(n)$ in Passiflora.

\begin{tabular}{lccc}
\hline \multirow{2}{*}{ Group } & \multirow{2}{*}{ DF } & \multicolumn{2}{c}{$\chi^{2}$ calculated } \\
\cline { 3 - 4 } & & $f$ of T and I chiasmata & $f$ of total chiasmata \\
\hline$n=6$ & 2 & $62.95^{* *}$ & $8.45^{*}$ \\
$n=9$ & 8 & $52.16^{* *}$ & $101.56^{* *}$ \\
$n=12$ & 1 & $14.58^{* *}$ & 0.66 \\
\hline
\end{tabular}

$* P<0.05 ; * * P<0.01$.

\section{Discussion}

The study of chromosome behavior at fertilizations and cell division determines the nature of inheritance, and their organization controls the activity of genes (Sumner 2003). The meiotic behavior was differentiated among Passiflora taxa, concerning both number and position of chiasmata, RI and MIx. In the 14 taxa studied, univalent chromosomes in diakinesis or metaphase I can have occurred due to the low chiasma frequency.

Table 5. Cells (\%) with meiotic irregularities and chromosome bridge in Passiflora $(\mathrm{M}=$ metaphase; $\mathrm{A}=$ anaphase; $\mathrm{T}=$ telophase; $\mathrm{I}=$ meiosis I; II = meiosis II).

\begin{tabular}{|c|c|c|c|c|c|c|c|c|c|c|c|c|c|c|}
\hline \multirow[t]{2}{*}{ Taxa } & \multicolumn{6}{|c|}{ Lagging/precocious chromosome } & \multicolumn{2}{|c|}{$\begin{array}{c}\text { Chromosome } \\
\text { bridge }\end{array}$} & \multicolumn{2}{|c|}{ Asynchrony } & \multicolumn{3}{|c|}{ Spindle irregulaties } & \multirow{2}{*}{$\begin{array}{l}\text { Three } \\
\text { nuclei } \\
\text { T II }\end{array}$} \\
\hline & M I & A I & T I & M II & A II & T II & A I & A II & M II & A II & M II & A II & T II & \\
\hline P. alata & 4.6 & 11.5 & 0.6 & 1.8 & 1.8 & - & 17.2 & 1.9 & 16.4 & 9.2 & 7.3 & 3.7 & 8.0 & - \\
\hline P. amethystina & 4.6 & 5.4 & 1.7 & - & - & - & 26.0 & 2.9 & 27.1 & 26.0 & 13.5 & 2.9 & 23.0 & - \\
\hline P. capsularis & 5.7 & 2.9 & 1.2 & 7.3 & 3.6 & 0.4 & 2.9 & 0.9 & 11.3 & 14.4 & 13.7 & 26.1 & 34.8 & 1.6 \\
\hline P. cincinnata & 10.3 & 10.0 & - & 5.7 & 6.7 & - & 4.0 & 13.5 & 9.4 & 6.7 & 16.6 & 12.3 & 38.1 & 3.5 \\
\hline P. edulis & 11.0 & 5.5 & 1.5 & - & 3.0 & - & 2.7 & 3.0 & 17.0 & 4.5 & 8.1 & 17.9 & 31.1 & 3.3 \\
\hline P. edulis f. flavic & 1.8 & - & - & 3.1 & 2.4 & - & - & 1.2 & 23.9 & 12.0 & 10.4 & 13.2 & 10.9 & - \\
\hline P. gibertii & 34.0 & 29.2 & 21.3 & 21.9 & 2.3 & 1.9 & - & - & 39.6 & 6.7 & 10.4 & 26.7 & 31.2 & 4.5 \\
\hline P. kermesin & 9.8 & 9.4 & 2.6 & 5.1 & 2.9 & 1.2 & 5.8 & 6.7 & 15.4 & 13.3 & 7.6 & 8.8 & 16.0 & 5.3 \\
\hline P. malacophyl & 1.5 & 5.9 & - & 0.9 & 2.9 & - & - & - & .2 & 2.9 & 8.2 & 7 & 10.7 & 3.6 \\
\hline P. mo & 2.3 & 4.5 & 2.9 & 8.4 & 6.9 & 3.2 & 6.0 & 3.4 & & 3. & 17.9 & 24.1 & 22.6 & 3.2 \\
\hline P. $m u$ & 16.2 & 18.2 & 6.6 & 3.4 & 1.2 & 1.6 & - & 0.6 & 2 & 6.5 & 19.1 & 11.8 & 24.6 & 4.9 \\
\hline P. pentag & 12.5 & 9.1 & 7.4 & 16.1 & 11.9 & 5.0 & 3.6 & - & 3.2 & 12.5 & 18.3 & 26.1 & 32.1 & 4.6 \\
\hline P. rubra & 6.7 & 5.9 & 6.9 & 2.6 & 4.1 & - & 1.4 & - & 17.3 & 24.5 & 3.8 & 10.2 & 18.6 & - \\
\hline P. suberosa & 24.9 & 16.8 & 12.2 & 12.7 & 5.1 & 1.9 & - & - & 12.7 & 16.9 & 20.0 & 15.1 & 37.1 & 4.8 \\
\hline
\end{tabular}




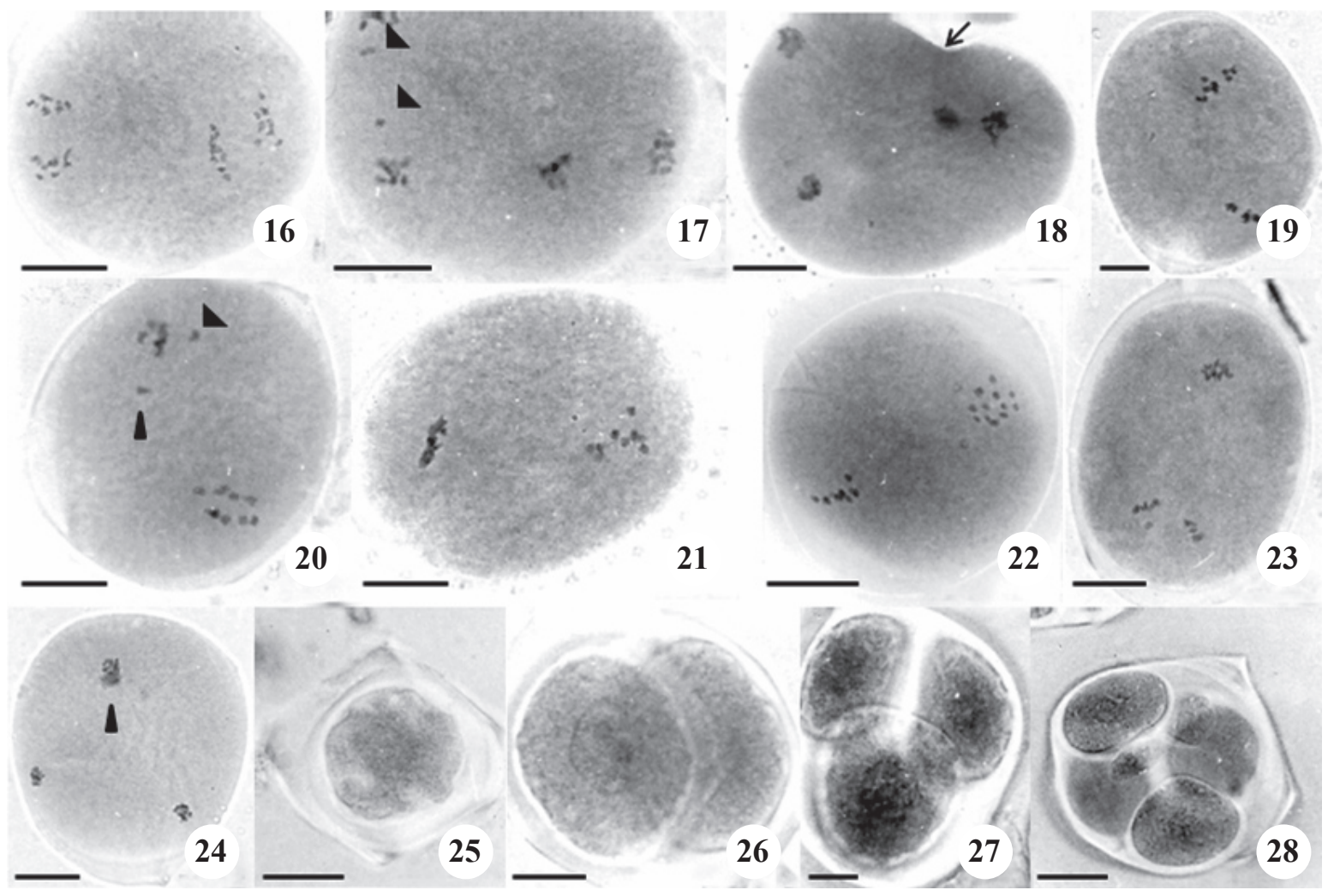

Figures 16-28. Meiotic and post-meiotic behavior in Passiflora. 16-20. Irregularities in the spindle orientation. 16. Anaphase II with transverse spindle in P. kermesina. 17. Anaphase II with tripolar spindle and precocious chromosomes (arrowheads) in P. gibertii. 18. Telophase II with irregular position of nuclei; cytoplasma can be divided forming a cell with two nuclei (arrow) in P. gibertii. 19. Metaphase II with tripolar spindle in P. gibertii. 20. Anaphase II with tripolar spindle and precocious chromosomes (arrowheads) in P. gibertii. 21-22. Asynchrony. 21. Irregular metaphase II in P. gibertii. 22. Irregular metaphase II in P. suberosa. 23. Irregular anaphase II in P. cincinnata. 24. Telophase II with three nuclei in $P$. kermesina, two nuclei in the same position (arrowhead). 25-26. Irregular post-meiotic products. 25. Degenerated cels in P. edulis f. flavicarpa. 26. Dyad in P. amethystine. 27. Triad in P. pentagona. 28. Polyad with with two microcytes in P. edulis f. flavicarpa. Bar $=20 \mu \mathrm{m}$.

Table 6. Mean values of normal tetrads, irregular post-meiotic products (PMP) and meiotic index (MIx) in Passiflora.

\begin{tabular}{|c|c|c|c|c|c|c|c|}
\hline \multirow{3}{*}{ Taxa } & \multicolumn{6}{|c|}{ PMP } & \multirow{3}{*}{$\begin{array}{l}\text { MIx } \\
(\%)\end{array}$} \\
\hline & \multirow{2}{*}{$\begin{array}{c}\text { Normal } \\
\text { tetrads }\end{array}$} & \multicolumn{4}{|c|}{ Irregularities } & \multirow{2}{*}{$\begin{array}{l}\text { Total } \\
\text { PMP }\end{array}$} & \\
\hline & & Monads & Dyads & Triads & Polyads & & \\
\hline P. alata & 535.2 & 0.7 & - & 43.0 & - & 579 & $92.4 \mathrm{c}$ \\
\hline P. amethystina & 548.0 & - & 3.2 & 9.2 & 0.7 & 561 & $97.7 \mathrm{a}$ \\
\hline P. capsularis & 363.7 & 0.3 & - & 55.3 & - & 382 & $95.2 \mathrm{~b}$ \\
\hline P. cincinnata & 750.2 & - & 0.5 & 54.0 & 0.7 & 806 & $93.1 \mathrm{c}$ \\
\hline P. edulis & 802.7 & - & 4.3 & 27.5 & 0.3 & 835 & $96.2 \mathrm{a}$ \\
\hline P. edulis f. flavicarpa & 939.8 & 0.8 & - & 20.3 & 0.8 & 962 & $97.7 \mathrm{~b}$ \\
\hline P. gibertii & 867.3 & 1.8 & 3.8 & 26.5 & 1.8 & 901 & $96.3 \mathrm{a}$ \\
\hline P. kermesina & 534.8 & 0.3 & 0.3 & 13.5 & 0.5 & 549 & $97.4 \mathrm{~b}$ \\
\hline P. malacophylla & 1015.0 & 0.5 & - & 19.0 & 0.5 & 1035 & $98.1 \mathrm{a}$ \\
\hline P. morifolia & 559.5 & - & - & 19.5 & - & 579 & $96.6 \mathrm{~b}$ \\
\hline P. mucronata & 629.5 & - & - & 24.3 & 0.5 & 654 & $96.2 \mathrm{~b}$ \\
\hline P. pentagona & 680.8 & 1.5 & 2.8 & 67.3 & 14.2 & 767 & $88.8 \mathrm{~d}$ \\
\hline P. rubra & 779.3 & 1.3 & - & 48.0 & 10.5 & 839 & $92.8 \mathrm{c}$ \\
\hline P. suberosa & 194.5 & 0.2 & 1.5 & 21.8 & 2.0 & 220 & $88.4 d$ \\
\hline
\end{tabular}

Means followed by the same letter do not differ by the Tukey test at $5 \%$ probability $(\alpha=0.05)$. 
Table 7. ANOVA summary for the different types of post-meiotic products in Passiflora (DF $=$ degree fredow).

\begin{tabular}{|c|c|c|c|c|c|c|}
\hline \multirow{2}{*}{ Source of variation } & \multirow{2}{*}{ DF } & \multicolumn{5}{|c|}{ Mean squares } \\
\hline & & Monads & Dyads & Triads & Tetrads & Polyads \\
\hline Taxa & 13 & 0.0499 & 0.3750 & $30.7455^{* *}$ & $53.0760 * *$ & 2.9910 \\
\hline Error & 42 & 0.0633 & 0.2830 & 10.1979 & 9.4837 & 2.1316 \\
\hline Coefficient of variation (\%) & & 26.19 & 24.99 & 6.87 & 3.25 & 31.25 \\
\hline
\end{tabular}

** $P<0.01$.

In passifloras, the total frequency of chiasmata varied in the $n=9$ group, being considered low mainly in $P$. alata, 8.7 per cell, and in the $n=6$ group, mainly in $P$. capsularis, 5.7 per cell. The RI varied among Passiflora taxa analyzed, $16.49 \%$ among the species with $n=6$ and $34 \%$ among species with $n=9$, which reflects the genetic variation among them. The mean number of chiasmata per bivalent is important for meiotic stability (Pagliarini 1990a), since bivalents are precociously separated if chiasmata are absents or in small number, resulting in univalents.

In interspecific hybrids of Passiflora, meiotic figures as univalents (Barbosa et al. 2007) and multivalents (Soares-Scott et al. 2003) were usually observed. But, though only bivalents are expected, different configurations of chromosome pairing were observed in Passiflora species in this work, as observed for other species of this genus. In P. edmundoi configurations as 7II+IV and 5II+2IV were observed (Souza et al. 2003a). High degree of chromosomal pairing and formation of chiasmata indicate homology of chromosomes or of chromosomal regions (Nikolova \& Niemirowicz-Szczytt 1995). In Passiflora, the species with lowest number of total chiasmata per cell tended to present higher number of laggard, precocious and univalent chromosomes.

Although chiasmata originate as a consequence of crossing-over, they also have an essential function in ensuring proper chromosome segregation at the first meiotic metaphase (Sumner 2003). Chiasmata are the only regions that hold homologous chromosomes together in late meiotic prophase. They prevent premature disjunction, and also help to ensure that the kinetochores of the homologous chromosomes that comprise a bivalent are oriented towards opposite poles of the cell (Sumner 2003). If chiasmata are precociously separated, or in small number or absent it can result in laggard chromosomes. Precocious chiasmata terminalization is atributed to the presence of univalents. Nowadays it has been concluded that chiasmata terminalization does not occur: the chiasmata remain at the sites where they appear until the disjunction of homologous chromosomes in anaphase I and the disjunction of homologues is accounted for the repulsion of the sister chromatids (Vysotskaya 1995). In hexaploid oats, the precocious chiasmata terminalization was suggested to be due to the low frequency of univalents at diakinesis but high in metaphase I (Baptista-Giacomelli et al. 2000). In this work, univalents at diakinesis were not registered and it was not possible to compare univalents' number of chiasmata at metaphase with chiasmata at diakinesis. Action of asynaptic and desynaptic events in the prophase I have not been related for Passiflora (Koduru \& Rao 1981).

Chromosomal homology is considered an essential event in the meiosis, which is necessary for chiasmata formation. Chiasmata and crossing over are generally located in specific segments of chromosomes, and the standard is genetically controlled (Sybenga 1999). In maize (Zea mays L.), the frequency of chiasmata is under polygenic control, which may lead to genetic variability in lineages (Pagliarini 1980). The polygenic chiasma control has also been demonstrated in rye, Secale cerale (Rees \& Thompson 1958, Lein \& Lelley 1987). The formation of chiasmata is a good characteristic, since it ensures the genetic variability of plants, thus having a direct influence on the adaptation mechanisms.

Many causes may lead to the occurrence of meiotic irregularities, such as lack of chromosomal homology resulting from hybridization, polyploidy, genetic and environmental factors (Pagliarini 1990a, b). The Passiflora taxa generally presented the highest percentages of meiotic irregularities, such as precocious chromosomes and asynchrony in the meiosis II, when the two nuclei are at different phases because they do not reach the same stage simultaneously, usually can be seen prometaphase and metaphase or metaphase and anaphase in the same cell. Chromosomal bridges were observed in passifloras without the presence of fragments.

Irregularities in the spindle fibers were present in higher percentages at the end of meiosis II, and were also responsible for post-meiotic abnormal products such as monads, dyads, triads and polyads. Some genes 
may affect the formation of spindle, especially during the meiosis II (Golubovskaya 1979). In passifloras, convergent spindles led to three-nuclei telophases ( $n$ and $2 n$ ), producing triads. Triads were also probably formed due to the asynchrony during meiosis II, which disturbed chromosome segregation. Anomalies in spindle organization have been reported in other species, such as Thunbergia mysorensis (Pagliarini 1990b), Centella asiatica (Consolaro \& Pagliarini 1996) and Zea mays (Caetano-Pereira et al. 1998).

The determination of MIx is a simple procedure to test regularity of meiotic process, and the higher the MIx, the more regular is the meiotic behavior (Love 1951). Most Passiflora species presented MIx higher than $90 \%$, which indicates that the several kinds of irregularities observed during the meiosis have influence on the formation of unviable pollen grains (Souza et al. 2004). According to Love (1951), plants with MIx higher than $90 \%$ may be considered cytologically stable, but actually it is not possible to guarantee such stability in plants with lower MIx, and generally it causes difficulties in interspecific hybridizations.

This study will help to choose the direction in which two species can be crossed, since the success of interspecific crossings is related to the genomic homology of parent species (Rao \& Rao 1984). Cytogenetic investigations, as behavior of chromosomes during the meiosis, may be considered important criteria to evaluate the level of genetic proximity between species and genotypes, through the observation of uniformity in chromosome pairing, or reveal the distance between them, as observed in Capsicum tovarii $\times$ C. baccatum hybrids that presented reciprocal translocations certifying the genetic distance between the parent species (Tong \& Bosland 1999).

Acknowledgements - The authors thank Wallen Rudeck S. Cock for collecting P. kermesina; Dr. Luís Carlos Bernacci (Instituto Agronômico - IAC, Campinas, Brazil) for the taxonomic identification of Passiflora species; Fundação Estadual do Norte Fluminense (FENORTE) and Fundação de Apoio à Pesquisa do Estado do Rio de Janeiro (FAPERJ) for financial support.

\section{References}

ABREU, P.P., SOUZA, M.M., SANTOS, E.A., PIRES, M.V., PIRES, M.M. \& ALMEIDA, A.A.F. 2009. Passion flower hybrids and their use in the ornamental plant market: perspectives for sustainable development with emphasis on Brazil. Euphytica 166:307-315.
AGUIAR-PERECIN, M.L.R., PAGLIARINI, M.S. \& VILLAMIZAR, N.R. 1984. Aspectos do controle genético da formação de quiasmas em milho. In Tópicos de citogenética e evolução de plantas (M.L.R. AguiarPerecin, O.S. Martins \& G. Bandel, eds.). SBG, Ribeirão Preto, p.111-123.

BAPTISTA-GIACOMELLI, F.R., PAGLIARINI, M.S., ALMEIDA, J.L. 2000. Chiasma frequency, distribution and terminalization in hexaploid oats (Avena sativa L.). Acta Scientiarum 22:269-273.

BARBOSA, L.V. \& VIEIRA, M.L.C. 1997. Meiotic behavior of passion fruit somatic hybrids, Passiflora edulis f. flavicarpa Degener $+P$. amethystina Mikan. Euphytica 98:121-127.

BARBOSA, L.V., MONDIN, M., OLIVEIRA, C.A., SOUZA, A.P. \& VIEIRA, M.L.C. 2007. Cytological behaviour of the somatic hybrids Passiflora edulis f. flavicarpa $+P$. cincinnata. Plant Breeding 126:323-328.

BEAL, P.R. 1969. Chromosome numbers of the exotic Passiflora species in Australia. Queensland Journal of Agricultural and Animal Sciences 26:407-421.

BEAL, P.R. 1971. Chromosome numbers in some recently introduced species of Passiflora in Australia. Queensland Journal of Agricultural and Animal Sciences 28:179180.

BIONE, N.C.P., PAGLIARINI, M.S., ALMEIDA, L.A. \& SEIFERT, A.L. 2002. An ms2 male-sterile, femalefertile soybean sharing phenotypic expression with other ms mutants. Plant Breeding 121:307-313.

BOWDEN, W.M. 1945. A list of chromosome numbers in higher plants. II. Menispermaceae to Verbenaceae. American Jounal of Botany 32:191-201.

CAETANO-PEREIRA, C.M., DEFANI-SCOARIZE, M.A., PAGLIARINI, M.S. \& BRASIL, E.M. 1998. Syncytes, abnormal cytokinesis and spindle irregularities in maize microsporogenesis. Maydica 43:235-242.

CERVI, A.C. 2005. Espécies de Passiflora L. (Passifloraceae) publicadas e descritas nos últimos 55 anos (1950-2005) na América do Sul e principais publicações brasileiras. Estudos de Biologia 27:19-24.

CONSOLARO, M.E.L. \& PAGLIARINI, M.S. 1996. Meiotic behavior, pollen fertility and seed production in Brazilian populations of Centella asiatica (L.) Urban (Umbelliferae). Cytologia 61:375-381.

CRUZ, C.D. 2006. Programa Genes: estatística experimental e matrizes. Editora UFV, Viçosa.

DARLINGTON, C.D. 1958. Evolution of genetic systems. Oliver and Boyd, London.

DEFANI-SCOARIZE, M.A., PAGLIARINI, M.S. \& AGUIAR, C.G. 1996. Meiotic behavior of inbred lines of maize (Zea mays L.). Nucleus 39:10-18.

FERREIRA, F.R. 2005. Recursos genéticos de Passiflora. In Maracujá - germoplasma e melhoramento genético (F.G. Faleiro, N.T.V. Junqueira \& M.F. Braga, eds.). Embrapa Cerrados, Planaltina, p.41-52. 
GOLUBOVSKAYA, I.N. 1979. Genetic control of meiosis. International Review of Cytology 58:247-290.

GOTTSCHALK, W. \& KAUL, M.L.H. 1980. Asynapsis and desynapsis in flowering plants. I. Asynapsis. Nucleus 23:97-120.

GUERRA, M. 1986. Citogenética de angiospermas coletadas em Pernambuco, I. Brazilian Journal of Genetics 9: 21-40.

HAROUN, S.A. 1996. Chromosome association and pollen fertility of parental and interspecific hybrids of Lycopersicon esculentum $\times$ L. hirsutum and L. pennellii. Genetica 98:103-106.

JANAKIAMMAL,E.K. 1945. Chromosome atlas of cultivated plants. George Allen and Unwin Ltd., London.

KODURU, P.K.R. \& RAO, M.K. 1981. Cytogenetics of synaptic mutants in higher plants. Theoretical and Applied Genetics 59:197-214.

LEIN, V. \& LELLEY, T. 1987. A separate control for frequency and within-bivalent distribution of chiasmata in rye (Secale cereale L.). Genome 29:419-421.

LI, W., YANG, J., PAN, Y.-F., GUO, G.-Q. \& ZHENG, G.-C. 2003. Chromosome localization of genes that control synchronous development of pollen mother cells in wheat. Caryologia 56:275-279.

LOPES, S.C. 1991. Citogenética do maracujá. In A cultura do maracujá no Brasil (A.R. São José, ed.) Funepe, Jaboticabal, p.201-209.

LOVE, R.M. 1951. Varietal differences in meiotic chromosomes behavior of Brazilian wheats. Agronomy Journal 43:72-76.

MARTIN, F.W. \& NAKASONE, H.Y. 1970. The edible species of Passiflora. Economic Botany 24:333-343.

MACDOUGAL, J.M. 1983. Revision of Passiflora L. section Pseudodysosmia (Harms) Killip emend. J. MacDougal, the hooked trichome group (Passifloraceae). $\mathrm{PhD}$ dissertation, Duke University, Durham.

MELO, N.F., CERVI, A.C. \& GUERRA, M. 2001. Karyology and cytotaxonomy of the genus Passiflora L. (Passifloraceae). Plant Systematics and Evolution 226:69-84.

NIKOLOVA, V. \& NIEMIROWICZ-SZCZYTT, K. 1995. Evaluation of meiosis in cucumber (Cucumis sativus L.) monohaploids. Caryologia 48:275-283.

OLIVEIRA, J.C. 1987. Melhoramento genético. In Maracujá (C. Ruggiero, ed.). Legis Summa, Ribeirão Preto, p.218-246.

OLIVEIRA, A.M.A. \& COLEMAN, J.R. 1996. Estudos citogenéticos de espécies do gênero Passiflora (Passifloraceae). Brazilian Journal of Genetics 9:134.

PAGLIARINI, M.S. 1980. Controle genético da freqüência de quiasmas em milho (Zea mays L.). Dissertação de mestrado, Universidade de São Paulo, São Paulo.

PAGLIARINI, M.S. 1990a. Meiotic behavior and pollen fertility in Aptenia cordifolia (Aizoaceae). Caryologia 43:157-162.
PAGLIARINI, M.S. 1990b. Instabilidade meiótica em Thunbergia mysorensis (Acanthaceae). Ciência e Cultura 42:83-87.

PEIXOTO, M. 2005. Problemas e perspectivas do maracujá ornamental. In Maracujá - germoplasma e melhoramento genético (F.G. Faleiro, N.T.V. Junqueira \& M.F. Braga, eds.). Embrapa Cerrados, Planaltina, p.457-464.

RAO, S.V. \& RAO, B.G.S. 1984. Studies on the crossability relationships of some spinous Solanum. Theoretical and Applied Genetics 67:419-426.

REES, H. \& THOMPSON, J.B. 1958. Genotypic control of chromosome behavior in rye. V. The distribution pattern of chiasmata between pollen mother cells. Heredity 12:101-103.

RUSHING, F. 2003. Tough plants for southern gardens: low care, no care, tried and true winners. Cool Springs Press, Nashville.

SENDA, T., HIRAOKA, Y. \& TOMINAGA, T. 2005. Cytological affinities and interfertilities between Lolium temulentum and L. persicum (Poaceae) accessions. Hereditas 142:45-50.

SYBENGA, J. 1999. What makes homologous chromosomes find each other in meiosis? A review and a hypothesis. Chromosoma 108:209-219.

SNOW, N. \& MACDOUGAL, J.M. 1993. New chromosome reports in Passiflora (Passifloraceae). Systematic Botany 18:261-273.

SOARES-SCOTT, M.D., MELETTI, L.M. \& RECCOPIMENTEL, S.M. 2003. Meiotic behaviour and pollen fertility in sexual and somatic hybrids of Passiflora species. Caryologia 56:129-138.

SOUZA, M.M., PEREIRA, T.N.S., VIANA, A.P., PEREIRA, M.G., BERNACCI, L.C., SUDRÉ, C.P. \& SILVA, L.C. 2003a. Meiotic irregularities and pollen viability in Passiflora edmundoi Sacco (Passifloraceae). Caryologia 56:161-169.

SOUZA, M.M., PEREIRA, T.N.S., SILVA, L.C., REIS, D.S.S. \& SUDRÉ, C.P. 2003b. Karyotype of six Passiflora species collected in the state of Rio de Janeiro. Cytologia 68:165-171.

SOUZA, M.M., PEREIRA, T.N.S., VIANA, A.P., SILVA, L.C. \& SUDRÉ, C.P. 2004. Pollen viability and fertility in wild and cultivated Passiflora species (Passifloraceae). Beiträge zur Biologie der Pflanzen 73:359-376.

STOREY, W.B. 1950. Chromosome numbers of some species of Passiflora occurring in Hawaii. Pacific Science 4:37-42.

SUMNER, A.T. 2003. Chromosomes - organization and function. Blackwell Publishing, North Berwick, UK.

TILQUIN, J.P., BROUWER, K. \& HORVAT, F. 1984. Unusual cytological patterns in microsporogenesis in a cultivar of Fucksia. I. Multiple spindle. Theoretical and Applied Genetics 67:413-417.

TONG, N. \& BOSLAND, P.W. 1999. Capsicum tovarii, a new member of the Capsicum baccatum complex. Euphytica 109:71-77. 
VANDERPLANK, J. 2000. Passion flowers. The MIT Press, Cambridge.

VIANA, A.P., PEREIRA, T.N.S., PEREIRA, M.G., SOUZA, M.M., MALDONADO, J.F.M. \& AMARAL JÚNIOR, A.T. 2003. Diversidade genética entre genótipos comerciais de maracujazeiro-amarelo (Passiflora edulis f. flavicarpa) e entre espécies de passifloras nativas determinada por marcadores RAPD. Revista Brasileira de Fruticultura 25:489-493.

VYSOTSKAYA, L.V. 1995. Terminalization of chiasmata: analysis of the phenomenon. Russian Journal of Genetics 31:545-552. 